\title{
Improve Critical Thinking Ability Through Augmented Reality Assisted Worksheets
}

\author{
Luh Devi Herliandry ${ }^{1, *}$ Heru Kuswanto ${ }^{2}$, Wahyu Hidayatulloh ${ }^{1}$
}

\author{
${ }^{1}$ Master of Physics Education, Faculty of Mathematics and Natural Sciences, Universitas Negeri Yogyakarta, \\ Indonesia \\ ${ }^{2}$ Department of Physics Education, Faculty of Mathematics and Natural Sciences, Universitas Negeri Yogyakarta, \\ Indonesia \\ *Corresponding author. Email: deviherliandry18@gmail.com
}

\begin{abstract}
Worksheets have a complex arrangement that can support the learning process. Augmented reality technology can also be integrated in worksheets for physics concepts. The population in this study was Class X SMAN 1 Kalasan and obtained XI MIPA 1 as the experimental class and XI MIPA 3 as the control class. Quasi-experimental with post-test control group design was used to measure the critical thinking skills of the group. Ability to think critically with instrument assessment essay questions with inference indicators, analysis, evaluation and assessment. The hypothesis of analysis used independent t-test with the help of SPSS and it was found that there were differences in critical thinking skills in the two sample groups. This shows that the use of worksheets with augmented reality integration can be used to train and improve physics critical thinking skills in physics harmonic material.
\end{abstract}

Keywords: Critical thinking ability, Worksheet, Augmented reality

\section{INTRODUCTION}

The development of science and technology in the $21^{\text {st }}$ century provides new challenges in the world of education, especially in physics. This challenge requires students to master the concepts of physics to be able to apply them in everyday life. Given that physics is the center of technological development, communication to transportation [1]. This has an impact on the migration of physics learning from inquiry to argument-based inquiry which is closely related to critical thinking [2]. Physics learning can train thinking to solve problems and explain various phenomena that exist around human life [3]. Of course, students will also get used to explaining the phenomena experienced in their environment by using physics concepts and critical thinking. This is what makes critical thinking ability the main reference in the learning process around the world.

Critical thinking skills are important to be developed in this era. This is in line with the $21 \mathrm{st}$ century worldwide goal of critical thinking [4]. This is because critical thinking skills are important for the personal life and professional life of students [5]. Critical thinking skills are categorized as cognitive processes that are based on reflective assessment, goals, and logical thinking to find solutions to problems [6]. This is connected to the 2013 curriculum applicable in Indonesia to develop critical thinking in the current era the industrial revolution [7]. The importance of developing critical thinking skills because it can determine the success of students in life. Good in solving problems to decision making [8]. Of course this is also important to be applied as a basis for learning physics and in accordance with the curriculum. Developing and training critical thinking skills in learning physics becomes It is important to remember students' learning needs which are increasingly complex and important, and students who have critical thinking will get used to analyzing problems and solving them.

However, it is the fact that critical thinking skills are still low [9]. The low ability to think critically is caused by the inability of students to understand physics content and apply it in everyday life [10]. One of the factors is that the media used is not able to attract attention in the learning process [11] which has an impact on the low interest in learning physics. Based on these problems, it is necessary to make efforts to develop and improve students' critical thinking in the 
physics learning process. One of the efforts that can be made by creating active learning through student worksheets. This can be done by combining worksheets with learning media. Given that the worksheet is a teaching material that includes material and discussion material to train thinking skills and learning independence [12]. Complex arrangements in worksheets help students develop their abilities.

Worksheets can be combined with various media such as augmented reality (AR) technology. This allows providing potential in presenting physics content with real experience. Basically, the ability of AR technology to display digital content through 2D, $3 \mathrm{D}$ computer graphics, audio to video to the real world at the same time [13] [14]. Based on the manufacturing method, AR is divided into two, namely recognition based on marker images and faces and certain objects such as trees and locations [15]. The marker or marker object will be detected by the phone camera and processed so that it can display $2 \mathrm{D}, 3 \mathrm{D}$, and video objects simultaneously [16]. This is in line with the times that the use of phones supports learning physics in schools [17] [18]. This technology provides great opportunities for innovations in the world of education to learn in new ways and tailored to modern learning interests.

Given that physics consists of abstract concepts, the learning process requires supporting media to explain, describe and illustrate these concepts. Learning media can also support knowledge transfer and thought processes. The learning system through AR technology makes it possible to provide learning experiences related to physical phenomena that are displayed in real life. The use of AR technology in physics learning is in line with the interests and learning styles of 21st-century students [19]. Visual technologies such as AR enable constructivist learning [20]. Researchers believe that AR provides an opportunity to create a more attractive learning environment [21]. It is important to do research to determine the critical thinking skills of physics through student worksheets assisted by augmented reality technology.

\section{RESEARCH METHOD}

Type of this research is quasi-experimental because there are still external variables that influence it. Table 1. Shows the research design using the posttest control group design.
Table 1. Design post-test control group design.

\begin{tabular}{|l|c|c|}
\hline Class Type & Treatment & Posttest \\
\hline Experiment & $\mathrm{X}$ & $\mathrm{O}_{1}$ \\
\hline Control & - & $\mathrm{O}_{1}$ \\
\hline
\end{tabular}

The population of this research were students of class X SMAN 1 Kalasan in the academic year 2019/2020 with a sampling technique, namely simple random sampling. The samples obtained were $\mathrm{X}$ MIPA 1 and X MIPA 3 as the experimental and control class, each of which amounted to 30 people. The treatment was given through student worksheets assisted by augmented reality in the experimental class and control class through conventional learning. Data from the critical thinking ability scores will be classified based on the categories [22] in Table 2.

Table 2. Critical thinking skill categories.

\begin{tabular}{|c|l|}
\hline Classifications & Categories \\
\hline $81.25<x \leq 100$ & Very High \\
\hline $71.50<x \leq 81.25$ & High \\
\hline $62.50<x \leq 71.50$ & Moderate \\
\hline $0<x \leq 43.73$ & Low \\
\hline
\end{tabular}

The test instrument used to measure critical thinking skills, namely the essay test meets the inference indicators, explains, evaluates, and analysis. Hypothesis testing used the independent t-test to determine differences in the critical thinking skills of physics in the experimental class and the control class

\section{RESULT AND DISCUSSION}

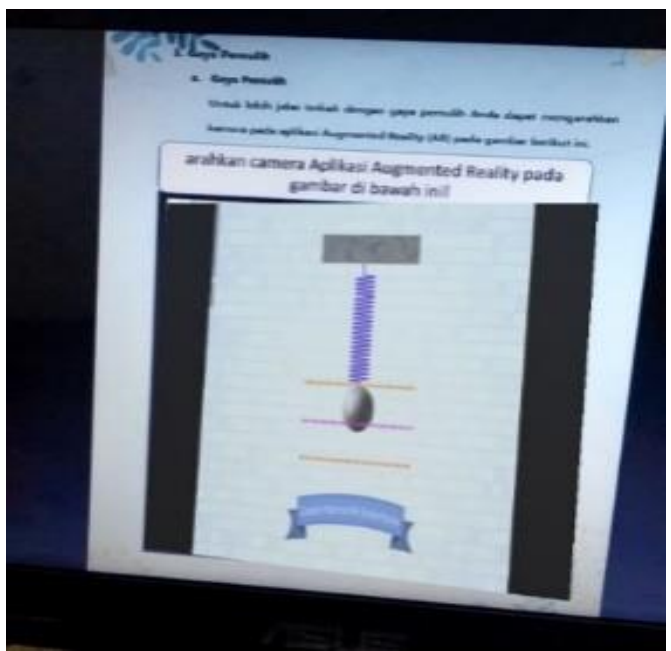

Figure 1. Display of Augmented Reality on a worksheet. 
This research was conducted during the COVID19 pandemic using online learning through google classroom. Treatment in the experimental class used augmented reality worksheets and control classes through conventional learning. The use of augmented reality through the marker image method available in the worksheet. Animated videos related to restorer style will be detected on the worksheet by the applications installed on the smartphone as shown in Figure 1.

The cognitive domain measured in this study is the ability to think critically using essay instruments. After being given the treatment, students were given a critical thinking ability test as many as 4 validated essay items. Critical thinking ability indicators include inference, evaluate, analysis and explain. The results of the critical thinking ability test analysis are presented in Table 3.

Table 3. show the difference in the average score of student's critical thinking skills in the sample group. The results obtained in the experimental class and control class were 65.73 and 74.86 . This shows that the experimental class average score is better, which is categorized as high and the control class is categorized as moderate. Normality and homogeneity tests were performed to determine the distribution of data in the two sample groups with the provisions (sig.> 0.05). The analysis carried out showed that the data of the two sample groups were homogeneous and normally distributed so that further tests could be carried out regarding the hypothesis. The results of the normality and homogeneity tests are shown in Table 4.

Table 5 displays the results of the hypothesis test using the independent $t$ test statistic using SPSS. The provisions ( $\mathrm{sig}<0.05)$ are used to provide conclusions. The data obtained shows that the sig. (2-tailed) of 0.010 which indicates that there are differences in critical thinking skills in the sample group. These results are also supported by the average score of critical thinking skills in the sample group in Table 3. The experimental class through augmented reality assisted worksheets has a better average score than the control class.

Augmented reality assisted worksheets play an important role in the learning process. Complex worksheet arrangements are able to train critical thinking skills and support active learning [23] [24]. Animated objects or videos that are combined in worksheets help students find physics concepts and support an independent learning environment [25]. This can stimulate the active role of students in analysis the concept of physics as a whole through the phenomena presented in the worksheet. Regarding the use of augmented reality-assisted worksheets, there are several reasons, namely that there are differences in the technological literacy abilities of each student.

Table 3. Critical thinking skill scores.

\begin{tabular}{|l|c|c|c|c|c|}
\hline Class Type & \multirow{2}{*}{ Student } & \multicolumn{4}{|c|}{ Critical Thinking Skill Scores } \\
\cline { 3 - 6 } & & Lowest & Highest & Average & Categories \\
\hline Experiment & 30 & 50 & 94 & 74.86 & High \\
\hline Control & 30 & 42 & 90 & 65.73 & Moderate \\
\hline
\end{tabular}

Table 4. Results of normality and homogeneity tests on critical thinking skills data.

\begin{tabular}{|l|c|c|c|c|c|c|c|}
\hline \multicolumn{2}{|c|}{ Class } & \multicolumn{3}{c|}{ Kolmogorov-Smirnov ${ }^{\text {a }}$} & \multicolumn{3}{c|}{ Shapiro-Wilk } \\
\cline { 3 - 8 } \multicolumn{2}{|c|}{} & Statistic & df & Sig & Statistic & df & Sig \\
\hline \multirow{2}{*}{ Critical Thinking } & MIPA 1 & 0.110 & 30 & 0.200 & 0.949 & 30 & 0.139 \\
\cline { 2 - 8 } & MIPA 3 & 0.086 & 30 & 0.200 & 0.968 & 30 & 0.484 \\
\hline
\end{tabular}

Table 5. Hypothesis test results through the independent t-test.

\begin{tabular}{|l|c|c|c|c|c|}
\hline & $d f$ & $\begin{array}{l}\text { Main } \\
\text { difference }\end{array}$ & $\begin{array}{l}\text { Std. Error } \\
\text { Difference }\end{array}$ & $\begin{array}{l}\text { Score } \\
\text { t-test }\end{array}$ & Sig. (2-Tailed) \\
\hline $\begin{array}{l}\text { Posttest Experiment - } \\
\text { Control Class }\end{array}$ & 58 & 9.13 & 3.42 & 2.66 & 0.010 \\
\hline
\end{tabular}




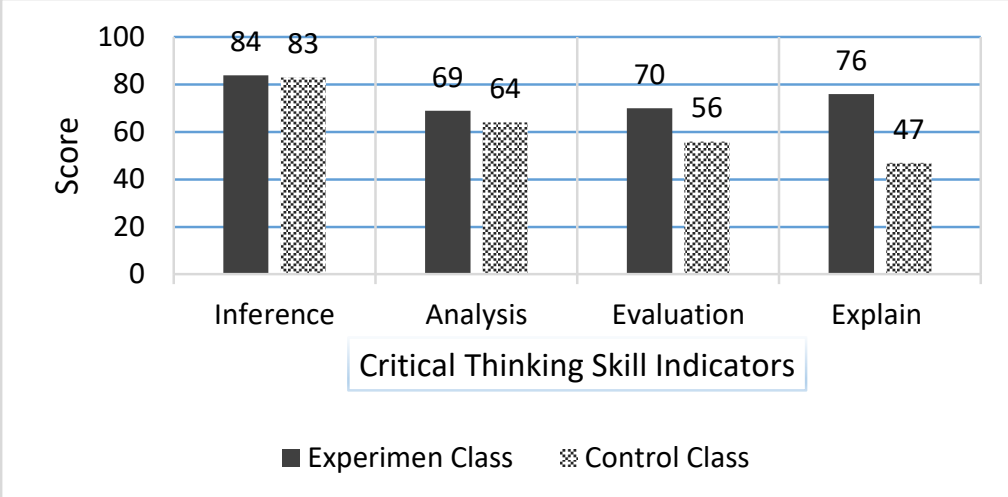

Figure 1. Critical thinking skill score on indicators.

Further analysis was also carried out on the average score of each indicator of critical thinking skills. Figure 1. Displays the level of critical thinking skills of students in terms of four indicators, namely inference, analysis, evaluate and explain. The results of the analysis on the average score of the inference indicator for the two classes have almost the same score. This indicator is contained in the material on the relationship of several variables in Hooke's Law. Students in both classes are able to provide arguments to conclude the relationship of the force variable $(\boldsymbol{F})$ with the increase in the length of the spring $(\Delta \boldsymbol{x})$ based on the graphic data presented in the questions. This concept is easily found in the daily life of students as the force exerted when pulling elastic objects.

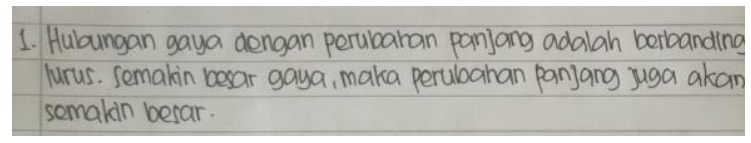

Figure 2. Examples of answers of experimental class students on inference indicator questions.

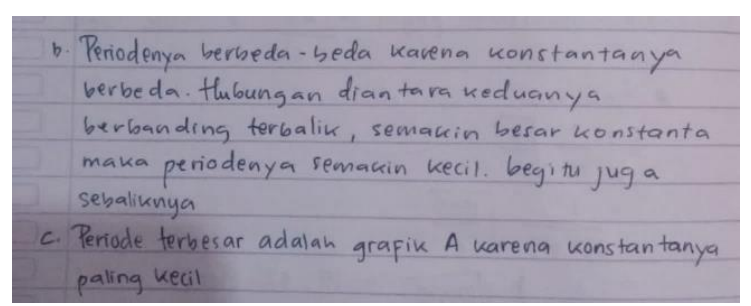

Figure 3. Examples of answers of experimental class students on explaining indicator questions.

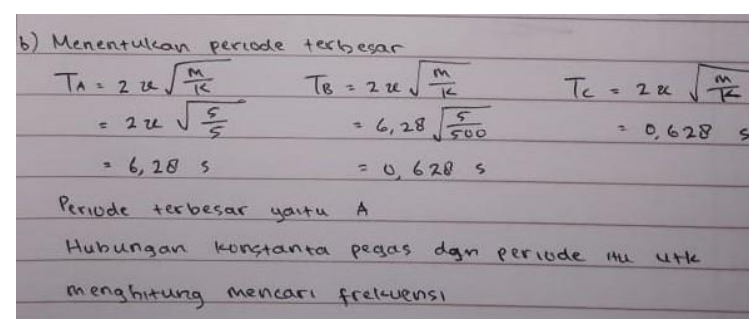

Figure 4. Examples of answers of control class students on explaining indicator questions.

The control class average score on the indicator explains that it has the lowest score compared to other indicators. The difficulty experienced by the control class is the inability to explain the relationship between variables based on the data or information presented regarding the concept of the period. In the experimental class, most students were able to explain the relationship of several variables related to the concept of the period and were able to draw conclusions from the information obtained as shown in Picture 4. Worksheets can stimulate students to think and process their knowledge which is supported by visual displays in augmented reality [25]. This makes learning through augmented reality-assisted worksheets even better [26]. This will make it easier for students to connect between variables of data or information and train their critical thinking skills.

Augmented reality assisted worksheets help students easily analysis simple harmonic vibration concepts. The integration of augmented reality on worksheets helps understand and shape thinking processes in students [27]. It also helps train and optimize critical thinking skills in physics [28] and facilitates learning [25] [29]. This proves that the use of augmented reality-assisted worksheets has a positive impact on learning physics.

\section{CONCLUSION}

There are differences in the critical thinking skills of physics in the two sample groups. The data show that critical thinking skills in the experimental class was higher than the control class. This shows worksheet assisted by augmented reality has an influence on students' critical thinking skills.

\section{REFERENCES}

[1] Abdurrahman, Liliasari, A. Rusli, B. Waldrip, Implementasi Pembelajaran Berbasis Multi Representasi untuk Peningkatan Penguasaan Konsep Fisika Kuantum, Cakrawala Pendidikan, 1 (2011) 30-45. 
[2] B. Hand, M.C. Shelley, M. Laugerman, L. Fostvedt, W. Therrien, Improving Critical Thinking Growth for Disadvantaged Groups Within Elementary School Science: A Randomized Controlled Trial Using The Science Writing Heuristic Approach, Science Education 102 (2018) 693-710. DOI: https://doi.org/10.1002/sce.21341

[3] M. Williams, The Missing Curriculum in Physics Problem-Solving Education, Science and Education $27 \quad$ (2018) 1-21. DOI: https://doi.org/10.1007/s11191-018-9970-2

[4] B.A. Danday, S.L.C. Monterola, Effects of Microteaching Multiple-Representation Physics Lesson Study on Pre-Service Teachers' Critical Thinking, Journal of Baltic Science Education 18 (2019) 695-696. DOI: https://doi.org/10.33225/jbse/19.18.692

[5] M.J. Bezanilla, D. Fernández-Nogueira, M. Poblete, H. Galindo-Domínguez, Methodologies for Teaching-Learning Critical Thinking in Higher Education: The teacher's view, Thinking Skills and Creativity 33 (2019) 1-10. DOI: https://doi.org/10.1016/j.tsc.2019.100584

[6] C.P. Dwyer, M.J. Hogan, I. Stewart, An integrated critical thinking framework for the 21st century, Thinking Skills and Creativity 12 (2014) 43-52. DOI: https://doi.org/10.1016/j.tsc.2013.12.004

[7] R. Zulmaulida, Wahyudin, J.A. Dahlan, WatsonGlaser's critical thinking skills, Journal of Physics: Conference Series, vol. 1028, IOP Publishing, Bristol, 2018, p. 012094. DOI: https://doi.org/10.1088/174$\underline{6596 / 1028 / 1 / 012094}$

[8] L.D. Herliandry, A. Harjono, J. 'Ardhuha, Kemampuan Berpikir Kritis Fisika Peserta Didik Kelas X dengan Model Brain Based Learning, Jurnal Penelitian Pendidikan IPA 5(1) (2018) 39-48.

DOI:

https://doi.org/10.29303/jppipa.v5i1.166

[9] R. Khasani, S. Ridho, B. Subali, Identifikasi Kemampuan Berpikir Kritis Siswa SMP Pada Materi Hukum Newton, Jurnal Penelitian Pendidikan IPA 5 (2019) $165 . \quad$ DOI: https://doi.org/10.29303/jppipa.v5i2.192

[10] S. Hamdi, I.A. Suganda, N. Hayati, Developing Higher-Order Thinking Skill (HOTS) Test Instrument Using Lombok Local Cultures as
Contexts for Junior Secondary School Mathematics, Research and Evaluation in Education 4(2) (2018) 126-135. DOI: https://doi.org/10.21831/reid.v4i2.22089

[11] I. Nofitasari, Y. Sihombing, Deskripsi Kesulitan Belajar Peserta Didik dan Faktor Penyebabnya dalam Memahami Materi Listrik Dinamis Kelas X SMS Negeri 2 Bengkayang, Jurnal Penelitian Fisika dan Aplikasinya (JPFA) 7 (2017) 44. DOI: https://doi.org/10.26740/jpfa.v7n1.p44-53

[12] F.D. Syamsu, Pengembangan Lembar Kerja Peserta Didik Berorientasi Pembelajaran Discovery Learning untuk Meningkatan Keterampilan Berpikir Siswa, Genta Mulia XI (2020) 65-79.

[13] P.M. O'Shea, Augmented Reality in Education, International Journal of Gaming and ComputerMediated Simulations 3 (2011) 91-93. DOI: https://doi.org/10.4018/jgcms.2011010108

[14] F. Bakri, O. Marsal, D. Muliyati, Textbooks Equipped with Augmented Reality Technology for Physics Topic in High-School, Jurnal Penelitian \& Pengembangan Pendidikan Fisika 5 (2019) 113-122. DOI: https://doi.org/10.21009/1.05206

[15] I. Mustaqim, Pemanfaatan Augmented Reality sebagai Media Pembelajaran, Jurnal Pendidikan Teknologi dan Kejuruan 13 (2016) 174. DOI: https://doi.org/10.23887/jptkundiksha.v13i2.8525

[16] A. Pramono, M.D. Setiawan, Pemanfaatan Augmented Reality sebagai Media Pembelajaran Pengenalan Buah-Buahan, INTENSIF: Jurnal Ilmiah Penelitian dan Penerapan Teknologi Sistem Informasi 3 (2019) 54. DOI: https://doi.org/10.29407/intensif.v3i1.12573

[17] N. Mardiana, H. Kuswanto, Android-assisted physics mobile learning to improve senior high school students' divergent thinking skills and physics HOTS, AIP Conference Proceedings, vol. 1868, AIP Publishing, Maryland, 2017, p. 070005 .

DOI: https://doi.org/10.1063/1.4995181

[18] M. Aydin, Investigating Pre-Service Science Teachers' Mobile Augmented Reality Integration into Worksheets, Journal of Biological Education (2019) 1-17. DOI: https://doi.org/10.1080/00219266.2019.1682639 
[19] M. Tomara, D. Gouscos, A Case Study: Visualizing Coulomb Forces with The Aid of Augmented Reality, Journal of Educational Computing 57 (2019) 1626-1642. DOI: https://doi.org/10.1177/0735633119854023

[20] J. Martín-Gutiérrez, C.E. Mora, B. Añorbe-Díaz, A. González-Marrero, Virtual Technologies Trends in Education, EURASIA Journal of Mathematics, Science and Technology Education 13 (2017) 469-486. DOI: https://doi.org/10.12973/eurasia.2017.00626a

[21] D.N.E. Phon, M.B. Ali, N.D.A. Halim, Collaborative augmented reality in education: a review, International Conference on Teaching and Learning in Computing and Engineering, Kuching, Malaysia, 2014, pp. 78-83. DOI: https://doi.org/10.1109/LaTiCE.2014.23

[22] Ermayanti, D. Sulisworo, Tingkat kemampuan berpikir kritis peserta didik setelah penerapan model pembelajaran student team achievement divisions (STAD) pada siswa sekolah menengah atas (SMA), Prosiding Seminar Nasional Quantum, Conference, Universitas Ahmad Dahlan, Yogyakarta, 2016, pp. 175-181.

[23] M. Firdaus, I. Wilujeng, Pengembangan LKPD Inkuiri Terbimbing untuk Meningkatkan Keterampilan Berpikir Kritis dan Hasil Belajar Peserta Didik Developing Students Worksheet on Guided Inquiry to Improve Critical Thinking Skills and Learning Outcomes of Students, Jurnal Inovasi Pendidikan IPA 4 (2018) 26-40. DOI: https://doi.org/10.21831/jipi.v4i1.5574

[24] D. Sumardani, A. Putri, Z. Ramadhan, F. Bakri, D. Muliyati, Augmented Physics' Lab: Magnetic
Field Use Virtual Learning Media for 21st Century Students, Jurnal Pembelajaran Fisika 8 (2019) 61-70. DOI: https://doi.org/10.23960/jpf.v8.n1.202007

[25] F. Bakri, S. Pratiwi, D. Muliyati, Video-enriched worksheet based on augmented reality technology: The heat experiment is easier, AIP Conference Proceedings, vol. 2169, AIP Publishing, Maryland, 2019, p. 020010. DOI: https://doi.org/10.1063/1.5132645

[26] J. Zhang, Y.T. Huang, T.C. Liu, Y.T. Sung, K.E. Chang, Augmented Reality Worksheets In Field Trip Learning, Interactive Learning Environments (2020) 1-18. DOI: https://doi.org/10.1080/10494820.2020.1758728

[27] H. Ardiny, E. Khanmirza, The role of ar and vr technologies in education developments: opportunities and challenges, RSI International Conference on Robotics and Mechatronics (IcRoM), Tehran, Iran, 2018, pp. 482-487. DOI: https://doi.org/10.1109/ICRoM.2018.8657615

[28] F. Bakri, E. Ervina, D. Muliyati, Practice the higher-order thinking skills in optic topic through physics worksheet equipped with augmented reality, AIP Conference Proceedings, vol. 2169, AIP Publishing, Maryland, 2019, p. 020006. DOI: https://doi.org/10.1063/1.5132641

[29] A. Syawaludin, G. Gunarhadi, P. Rintayati, Development of Augmented Reality-Based Interactive Multimedia to Improve Critical Thinking Skills in Science Learning, International Journal of Instruction 12 (2019) 331-344.

DOI: https://doi.org/10.29333/iji.2019.12421a 